\title{
Predetermination and Nihilism in W. B. Yeats's Theatre
}

\author{
Francisco Javier Torres Ribelles \\ University of Alicante
}

\begin{abstract}
This paper puts forward the hypothesis that Yeats's theatre is affected by a determinist component that governs it. This dependence is held to be the natural consequence of his desire to create a universal art, a wish that confines the writer to a limited number of themes, death and old age being the most important. The paper also argues that the determinism is positive in the early stage but that it clearly evolves towards a negative kind. In spite of the playwright's acknowledged interest in doctrines related to the occult, the necessity of a more critical analysis is also put forward. The paper goes on to suggest that underlying the negative determinism of Yeats's late period there is a nihilistic view of life, of life after death and even of the work of art. The paper concludes by arguing that the poet may have exaggerated his pose as a response to his admitted inability to change the modern world and as a means of overcoming his sense of impending annihilation.
\end{abstract}

The attitude underlying Yeats's earliest plays is radically opposed to what we find in the final ones. In the first stage, the determinism to which the subject matter inevitably leads is given a positive character by being adapted to the author's perspective. There is an emphasis on the power of art and a celebration of the Nietzschean-romantic values defended by the poet. In contrast, the last stage is one of pessimism, and the need to express it coincides with his greater dramatic capacity and the command of new techniques which lend even more personal dimensions to his symbolism. Between these two extremes, the playwright progresses from detachment to closer involvement when dealing with the themes of death and old age.

For Yeats, the main themes of high art are those inherent in man. Only by resorting to the common links existing between human beings in all ages can the limits of the individual be overcome and the work of art be given a classical and transcendental identity. This accords with his vision of the relationship of mankind with collective memory, according to which the contact with the Anima Mundi can only be made possible by an artist if he relies on what has preoccupied the human race throughout history, 
"hopes and alarms common to every man that ever came into the world." This notion, which justifies his dependence on tradition, accounts for his inclination to primitivism, considered as the state in which man is troubled only by essential emotions; at the same time, this view of the need to create an ecumenical art also helps to explain his rejection of artists who are concerned exclusively with the contemporary world, for he identifies their work with circumstantial interests. ${ }^{2}$

Yeats's work rests on two main complementary foundations: his reliance on an ecumenical subject matter; and his belief that art is the indispensable means to proclaim the falseness of reality and to liberate us from the material world through the intensification of the senses and the imagination. The latter gives rise to most of the formal features and symbolic imagery in his theatre, as well as to his attempts to generate an atmosphere of dream and an obvious theatricality as means of escaping the sensible world. The former ensures that the main themes of his works are those which, according to him, have preoccupied man through the centuries. For him they are love, old age, and death:

We must then be artists in all things, and understand that love and old age and death are first among the arts. ${ }^{3}$

His insistence on these two aesthetic principles conditions the evolution of his theatre.

Thus, in his first period, though his Symbolist vision of art materializes in an elaborate formal beauty, as regards subject matter, love, death, and old age, his treatment is optimistic. The distance from which Yeats views death and old age allows him to take advantage of them and to deal passionately and idealistically with love. The outcome is an identification of the idea of death with life. The assimilation is combined with a positive determinism, and the complex effect that results can be seen in plays such as The Countess Cathleen, where the protagonist's decision to sell her soul leads her to exaltation and eternal life. Something similar happens in Cathleen ni Houlihan, for a prophesied ending impels young Michael to a patriotic death and everlasting fame. The conclusion of The Shadowy Waters should be understood in the same way, as happiness abides in the vague destiny of the two main characters. The Land of Heart's Desire, in which Mary's choice implies the attainment of a fully intense existence, is the epitome of this equation of life and death, as well as of the praise of youth and of the rejection of old age. Her decision allows her, through premature death, to liberate herself from the action of "Fate and Time and Change." Through the book she reads, Mary finds a model for her own behaviour. In this way, art offers an attractive alternative to the mediocrity of daily life.

Yeats's attitude changes, however, with the evolution of his theatre. During the years in which the Cuchulain cycle begins to take shape, a change in his point of view occurs, and in At the Hawk's Well it is possible to find a new perspective in the contrast of the figure of the young hero and the Old Man.

In At the Hawk's Well, Yeats sets the two extremes of human existence against each other: on one side the prime of youth, represented by Cuchulain; and opposing it, the decay of old age, embodied in the Old Man. Compared to the first plays, the determinism is now far from being positive. The playwright emphasizes the Old Man's senility while at the same time foregrounding the defects of his contrary. Significantly, these are the defects 
which have brought the Old Man to his present condition. The Young Man's repetition of the same mistakes, which reveals the cyclic nature of time and draws him near the other character, increases the sensation of man's helplessness to decide upon his own destiny. Apart from heightening unreality and theatricality, the stage directions of the play, which indicate that the movements of the actors should suggest those of marionettes, distinctly contribute to the construction of an atmosphere of negative predestination. ${ }^{5}$

After At the Hawk's Well Yeats's theatre diverges even further from positive determinism. This development suggests a growing personal involvement in the themes which his earlier aloofness had enabled him to view positively, as with his first plays, or even regard more or less objectively, as happened with At the Hawk's Well and the other three texts of the first phase of the Cuchulain cycle.

If Sophocles' King Oedipus is the expression par excellence of fatalism, ${ }^{6}$ The Words upon the Window-Pane marks the beginning of a movement towards nihilism. Contrary to what happened in Yeats's first dramatic works, in which death was equated with a state of happiness deemed, at times, to be superior to life, it is now the after-life which is affected by the painful past that preceded it. The connexion between the two worlds of the play, the Dublin scene and the timeless domain in which the past events of the eighteenth century exist, takes place in the medium herself, in parallel with Yeats's ideal image of the true artist, who has to plunge into universal memory and become the link between that mystical realm and the present. Yet through her apprehension of intangible knowledge, Mrs Henderson suffers the affliction that impregnates the deeper regions in the play, and even unconsciously adopts the personality in which bitterness is concentrated, as becomes slear from her last words: "[She ... speaks in Swift's voice] Perish the day on which I was jorn!"”

In later texts, the nihilistic atmosphere becomes more intense, and in The Herne's Egg $t$ is possible to find transmigration, a question closely related to spiritualism, treated in a Nay which raises doubts about Yeats's position in his last years with regard to spiritualistic foctrines. This should encourage us at least to reflect critically on the real dimensions of lis beliefs in his late period as they are expressed in his works, especially if we bear in nind the close mutual dependence of his thought and his artistic production. Many cholars confirm Yeats's faith in these doctrines, and they seem to have the backing of the laywright's words and deeds, for he showed all his life a great interest in esoteric nowledge, as is proved by his printed texts, and by the some eighty thousand handwritten lages which have become accessible since 1976 . On the other hand, this interest is a ogical outcome of his rejection of positivist science and his notion of art as a true way to nowledge. Nevertheless, in spite of their emphasis on his belief in immortality, recent ritical works acknowledge the continuous change in his positions. For Allen, "there is no uestion that Yeats continually explored, investigated, adjusted and adapted" and "the 'egree of 'deepness' with which Yeats believed varied some from idea to idea, from ircumstance to circumstance, and from time to time during his life." ${ }^{8}$ In the same way, ieorge Mills Harper inadvertently removes the obstacles for admitting the playwright's tter scepticism when he deals with Yeats's wife's spiritual revelations that contributed to ie making of $A$ Vision. Despite stressing the poet's belief, which wavered only "in degree nd about details," he defines Yeats's personality by saying: "He was sceptical and he 
required proof, as I have pointed out in many instances; and changed his views gradually, as he did about almost all his psychical and religious experiments." In spite of his efforts to avoid it, Harper's implicit contradiction amounts, in the end, to a confirmation of what Whitaker had already stated: "if he was sometimes credulous, he was often shrewdly skeptical." 10

The theory of reincarnation adopted by Yeats considers human existence as an ephemeral period, a cycle of deceptive appearance within a longer, occult one. In essence, man initiates his sensory life through birth and escapes from it in death. This is consistent, therefore, with the thought behind his first plays, in which predetermination made the protagonists depart from a still somewhat attractive life in search of a superior, noble reality. Even in the version of Sophocles' King Oedipus published en 1928, in which fatality makes life an undesirable condition rejected by the main character when he blinds himself, death is still presented as the ideal state, free from pain, as the verses of the chorus proclaim as a sort of moral ending the play:

Make way for Oedipus. All people said,

'That is a fortunate man';

And now what storms are beating on his head!

Call no man fortunate that is not dead.

The dead are free from pain. ${ }^{11}$

In The Herne's Egg, however, a growing scepticism towards metempsychosis may be perceived in the irony with which Congal's ending is offered. Beneath the farcical, and doubtless provocative, surrealism pervading the text, the conclusion, with the grotesque transformation of the character into an engendered donkey, not only underlines Congal's stupidity but also makes Yeats's doctrines concerning reincarnation and the existence of a profound, wider cycle ambiguous. This is an attitude parallel to the one hinted at in The Player Queen - a play which may be deemed to show vestiges of positive determinism - where the equivocal figure of the Beggar had already formulated the doubt in words with Shakespearean resonances:

Decima ... Do those who are dead, old man, make love and do they find good lovers? Old Beggar I will whisper you another secret. People talk, but I have never known of anything to come from there but an old jackass. Maybe there is nothing else. ${ }^{12}$

Although The Words upon the Window-Pane is more pessimistic than Yeats's version of Sophocles' play, in that it admits there is pain after death, it still shows a spiritual world following the material one. However, the comic ambiguity in The Herne's Egg may well express Yeats's doubts about the after-life. If this were the case, the end of life would be viewed as mere annihilation, and man's own existence would be the only universe he could inhabit. This would explain the pessimism which underlies the late plays, in which the combination of determinism and existentialism leads, in a last movement, to a nihilistic view of life. The latent scepticism in The Herne's Egg becomes more evident in Purgatory 
and The Death of Cuchulain, which may be seen as the culminating results of this negative point of view.

Purgatory, which, like previous plays, presents the antithesis of youth and old age, again raises the question of the elimination of descent at the hands of the ancestor, a theme which Yeats had already dealt with in On Baile's Strand. On this occasion, however, far from the heroic age, there is a sense of hopelessness which is further stressed by the absurdness permeating the play.

Yeats contrasts two characters personifying extreme stages of vitality: one, youthful, has before him the future life can offer; the other, aged, lives in the deepest decadence, where nothing can be expected but death. Unlike the events in At the Hawk's Well, however, the confrontation is not balanced, but takes place in a domain in which the latter character prevails. The images that delineate the dramatic articulation of the senile mind reveal, in their conjunction with the reality of the world of the play, another sickly reality built upon tormenting memories, which is what life has been reduced to. In addition, the scenography and language emphasize decay, decisively upsetting the objectivity of our vision. Everything centres on the mind of the embittered old man who remembers; and even the deeper level seems to exist in his head only, contrary to what happens in The Words upon the Window Pane. On the other hand, whereas in On Baile's Strand the hero murdered his son because of his own shortcomings, which were revealed through the flaws of the subordinate characters, nonsense, embodied in the Old Man's insanity, is now the cause of the destruction of youth by old age. This can be interpreted as a more pessimistic dramatization of fatalism. When the Boy asks the Old Man "What if I killed you? You killed my grand-dad,/Because you were young and he was old./Now I am young and you are old," which seems to be a logical conclusion, the response is the reverse of what we might expect, and the son is slain by his father. ${ }^{13}$ As a complete expression of the tragedy of existence, the child destroys his father and then, when he grows old, slays his son in turn. Through this metaphor of the human being, whose birth symbolizes the end for his begetter, and whose old age represents the death of his own youth, the absurdity of the play reflects the absurdity of life.

In this way, making use again of a technique of chronological reduction, which becomes a symbol of the relativity of time and of the brevity of existence, Yeats offers a double perspective on mortality. This interpretation allows us to go beyond the traditional explanation of the text as a rejection of what is not aristocratic or noble because of its corrupt nature, or as a mere materialization of the depths of a character's mind. Within the frame of Yeats's central subject matter it is possible to regard the crime in Purgatory as the dramatic manifestation of man's bitterness in the face of his destiny. Furthermore, if we establish a parallel between what we are shown on stage and what the Old Man sees inside the window, the play may be understood as the outcome of the pessimism resulting from the preoccupations which have always been present in Yeats's theatre:

What were his life soon done!

Would he lose by that or win?

A mother that saw her son

Doubled over a speckled shin, 
Cross-grained with ninety years, Would cry, 'How little worth Were all my hopes and fears And the hard pain of his birth. ${ }^{14}$

For Yeats, misfortune is in man himself. Determinism underlies existence because it is in man's own nature that the germ of his annihilation lies. Thus, within the ludicrous comedy of The Herne's Egg, in Congal's question about his own possible folly, "Am I myself a Fool?/For if I am a Fool, he wins the bout" 15 — which is very difficult to construe because of its ambiguity - a more profound reality is couched: the fact that the Fool, whose intention is to kill the protagonist, is his reflection, as happens with the secondary characters in On Baile's Strand..$^{16}$ This points, in consequence, to man's imperfection as the origin of determinism.

If nihilism is latent in Yeats's mature plays and becomes more and more manifest in his late dramatic works, it reaches its most elaborate expression in his last version of The Death of Cuchulain. That Yeats's involvement with his work is greater on this occasion is a hypothesis that seems to be confirmed by the circumstances in which the text was produced, near the end of his life. ${ }^{17}$

Yeats's last dramatic production is very complex because of the special characteristics of its introduction and of the difficult allusions of the song ending it. It begins with a realistic 'prologue', moves into a mythical universe, in which the inner play takes place, and ends in a world of reality. The inmost core, where the supreme Irish hero's death is presented, is, therefore, affected by the two realistic fragments framing it, a fact that must be taken into account in any reading of the text.

Irony characterizes the prologue. The three musicians, who disappeared from the stage in Yeats's last years, have been replaced with an acrimonious old man who harasses the audience.$^{18}$ His references to his origin and aesthetic inclinations, and his claim to have had a predominant role in the production of the play, which can be interpreted as a metaphor for the gestation of the text, suggest his identification with the author. This, as well as the overt allusions to Yeats and his theatre, turns the playwright into an explicit element of the drama as it develops before the spectator.

Through the inclusion of the external character, described as " $a$ very old man looking like something out of mythology," Yeats expresses manifestly not only his rejection of modern art, but also his irony about his own person, his concerns and the decay of old age: "I have been selected because I am out of fashion and out of date like the antiquated romantic stuff the thing is made of." humour, the sour tone betrays an underlying bitterness. At the same time, the Old Man's words, which provide essential clues for the comprehension of the whole work, anticipate a summary of what will happen in the inner play, thus contributing to the predetermination presiding the mythical world.

In the central portion of the text, the hero is presented as a part of a cosmos on whose evolution he depends and to whose laws he is subject. In the instant of his death he experiences the full force of its indifference, 'personified' in the coldness and detachment with which the Blind Man of On Baile's Strand kills him. As happens with Hector, Achil- 
les, and many others, Cuchulain's victories prove to be incomplete when he is faced with the final defeat of his own annihilation, inherent in his nature. Yet the most outstanding feature of Yeats's treatment of the theme is his emphasis on indifference. ${ }^{20}$

The predetermination ruling the inner play can be understood as a reflection of Yeats's pessimistic nihilism. In the hero's fate, which he cannot escape, it is possible to perceive the playwright's awareness of his own death, which also seems to underlie the last section of the text.

When we leave the timeless mythological world, we are brought back again to reality, as if we had awoken from the dream of Cuchulain's death. After the stage darkens slowly and brightens again, "loud music ... of some Irish Fair of our day" introduces the words of one of the three Yeatsian musicians, who have significantly turned into the three ragged street-singers to whom the Old Man in the prologue had said he was going to teach Homer's music. Those words oppose "the harlot" to "the beggar-man," who is an allusion to the blind Greek poet. ${ }^{21}$ As the first line seems to indicate and the last two confirm, the song retells what the harlot sang to the beggar-man. Meanwhile the latter's silence is eloquent.

The song is composed of three stanzas which are based on the temporal juxtaposition of three different periods by means of a complex network of references: the remote, mythological past, the recent, historical past, and the personal present, which are related by the narrator's voice. The first stanza acts as a link with the inner play, since it introduces the mythical past into the quasi-reality of the last portion by referring to relevant figures of the legendary Irish world. The song, however, emphasizes the contrast between their attractiveness and their immateriality, suggesting that they are beyond the harlot's reach. In this way, since the prevailing point of view is hers, the first sign of the predominance of the material, modern world is given, and a bridge to the prologue's bitterness is established. The second stanza, through allusions to Pearse and Connolly, focuses on the immediate past and questions the mutual influence of tradition on the present and of the heroic actions of the present on the permanence and the paradigmatic qualities of myth. The third stanza relates both periods with a still more personal present time, which is evidence of Yeats's more direct involvement.

Far from being optimistic, the song is at least ambiguous. Positive feelings seem to derive from the second stanza, which suggests a solid bond with the heroic past revived by the patriots' sacrifice. Nevertheless, the final references to Cuchulain and Sheppard's statue can be considered a negative element. The implicit contrast of the hero with the present stresses the feeling of frustration which inevitably emanates from the cold objectivity of the harlot's tale, in contrast to the intensity generated by the heroic images:

No body like his body

Has modern woman borne,

But an old man looking back on life

Imagines it in scorn.

A statue's there to mark the place,

By Oliver Sheppard done

So ends the tale that the harlot 
Sang to the beggar-man. ${ }^{2}$

The song ending The Death of Cuchulain may be regarded as another contrast between physical, objective, material, perishable reality and spiritual, subjective, everlasting art. Yeats aesthetically develops the tension between the two domains through the dramatic comparison of temporal spheres. Yet though the song makes the three periods approach each other, in an apparent meeting of contraries, the balance is upset by the fact that the Street-Singer recites the harlot's words - the expression of the material world - whereas the beggar-man - the voice of immortal art - keeps silent. The insurmountable distance between the past and the modern world is established and the impossibility of escaping the present and the decay of physical substance is clearly exposed.$^{23}$ In the last stanza, therefore, Yeats's consciousness of his old age seems to emerge, together with his negative attitude to the world, his own life, and even his own work. He would be giving, then, a last disappointed confirmation to the doubts underlying previous texts, like "Sailing to Byzantium," where art was presented as the means of overcoming the decay of the physical world.

In the first poem of The Tower Yeats upholds an elevated world of art and the intellect against modern reality and the cult of ephemeral youth. He also praises a universe of the spirit that affords liberation from the desires and frustrations inherent in physical substance, which he claims he no longer wishes to assume. Yet it is possible to perceive uncertainty beneath his words. The acknowledgement of his own old age and the necessity of resorting to the "artifice of eternity," unavoidably convey such a feeling. ${ }^{24}$ The coincidence of part of the ideal chosen image, "a form as Grecian goldsmiths make/Of hammered gold and gold enamelling/To keep a drowsy Emperor awake," with a pejorative, ironical one in The King's Threshold, also stresses the negative sensation. ${ }^{25}$ In the same way, the admission of the influence of old age on his possible refusal of Cuchulain's body - which might have been taken for the symbol of the vitality of his art and the ambiguous reference to the hero's statue suggest feelings close to those underlying "Sailing to Byzantium," though now more pessimistic.

With their praise of the hero, explicitly contrasting him with the present, and implicitly comparing him with his statue in the hall of the Dublin Post Office, the concluding verses of The Death of Cuchulain are Yeats's last manifestation of his rejection of the modern world. This recurring characteristic of his plays had early been formulated in a prophetic tone after describing the champion's virtues at the end of The Green Helmet:

And these things I make prosper, till a day come that I know,

When heart and mind shall darken that the weak may end the strong, And the long-remembering harpers have matter for their song. ${ }^{26}$

For Yeats, the modern world is the result of the victory of the slave morality. Progress makes use of empirical reasoning and of lower art to annul independent, distinguished individuals, and materializes in heterogeneity, without taking into account the traditions of ancient times. ${ }^{27}$ Urban culture is its most outstanding expression.

In accordance with his concept of history as a cycle, Yeats sees modern times as the lowest stage in a process of decadence. For him, the personalities of the different individuals are, in consequence, no more than grotesque shadows resulting from the fragmentation of the classical personality, which deteriorates more and more with each 
generation. This idea was stated in Cuchulain's premonitory words in On Baile's Strand before killing his son:

\author{
Boy, \\ If I had fought my father, he'd have killed me, \\ As certainly as if I had a son \\ And fought with him, I should be deadly to him; \\ For the old fiery mountains are far off \\ And every day there is less heat o' the blood. ${ }^{28}$
}

In Yeats's mature period, his vision of history as a process of decadence strengthened. This led him to distance himself even more from modern democratic systems and increased his sympathy with the ultranationalist totalitarian movements that appeared in Europe in the twenties. ${ }^{29}$

The aristocratic values, opposing the degeneration of society, represented for Yeats the preservation of the classical virtues, and therefore, the example to imitate in the search of the nobility of mind which would be possible owing to the changes that the wheel of history would bring about. ${ }^{30}$ The inevitability of imminent change, which was an optimistic factor in his vision, and which he related to the triumph of the arts, must result in the advent of the superhuman, a figure embodied in his theatre in the aesthetic, racial model, the mythological hero. ${ }^{31}$

In his last period, Yeats moves, however, in a pessimistic duality. Underlying his apparent confidence in the impending change and in the power of art is the hopelessness caused by the irresistible decay of old age and the imminence of his death. That feeling results in a deep awareness of the predominance of reality and of his incapacity to change it, as well as in the appearance of serious doubts about the real importance of his own work. This situation forces him to resort to a pose as the only answer to his powerlessness.

In the adoption of his mask, which becomes more and more necessary as he gets older, Yeats counterbalances the decadence of the world surrounding him and the impossibility of surmounting predestination with the energy and the joy of creation, in "a gesture of defiance against death." 32 Both merge in a proud theatrical posture of cold Nietzschean detachment, which he opposes to the universe's indifference to man's fate:

There is in the creative joy an acceptance of what life brings, because we have understood the beauty of what it brings, or a hatred of death for what it takes away, which arouses within us, through some sympathy perhaps with all other men, an energy so noble, so powerful, that we laugh aloud and mock, in the terror or the sweetness of our exaltation, at death and oblivion. ${ }^{33}$

As a reaction against the inescapable reality of the world and the inevitability of destruction, Yeats's pose and his recourse to artistic creation allow him to face with dignity his desperation over old age and the proximity of his death. This is symbolized in Cuchulain's last action, which makes his end honourable, contrary to what happens to Congal. Just as the ultimate hero of his theatre fastens himself to a pillar-stone with his 
belt to await his end on his feet, Yeats stands with his art facing his own annihilation, to which the determinism of his human condition binds him.

\section{Notes}

1. W. B. Yeats, "The Well of the Saints," Essays and Introductions (London: Macmillan, 1961; reimpr. 1985), pp. 301-302.

2. "... those themes we share and inherit, so long as they engage our emotions, come first," "Introduction," ibid., ix; cf. "Discoveries," ibid., p. 286.

3. "Blake's Illustrations to Dante," ibid., p. 139. "Men did not mourn merely because their beloved was married to another, or because learning was bitter in the mouth, for such mourning believes that life might be happy were it different, and is therefore the less mourning, but because they had been born and must die with their great thirst unslaked. And so it is that all the august sorrowful persons of literature, Cassandra and Helen and Deirdre, and Lear and Tristan, have come out of legends and are indeed but the images of the primitive imagination mirrored in the little looking-glass of the modern and classic imagination. This is that 'melancholy a man knows when he is face to face' with Nature, and thinks 'he hears her communing with him about' the mournfulness of being born and of dying," "The Celtic Element in Literature,"' ibid., p. 182.

4. R. K. Alspach, ed., The Variorum Edition of the Plays of W.B. Yeats (London: Macmillan, 1966; reimpr. 1989), p. 190.

5. Variorum, p. 401.

6. Yeats's first version of Sophocles' King Oedipus is dated 1912. R. Ellmann, Yeats: The Man and the Masks (London: Faber and Faber, 1949; reimpr. 1973), p. 22; cf. Variorum, p. 809.

7. Variorum, p. 956.

8. J. L. Allen, "Yeats, Belief, and ESP: New Critical Attitudes," Eire-Ireland: A Journal of Irish Studies, 24, 1 (1989), 109-119, 118-19.

9. G. M. Harper, The Making of A Vision: A Study of the Automatic Script (London: Macmillan Press, 1987), p. 410.

10. T. Whitaker, Swan and Shadow: Yeats's Dialogue with History (Chapel Hill: The University of North Carolina Press, 1964), p. 15, my italics.

11. Variorum, pp. 850-51. A collation of Yeats's compressed version with the original text brings out significant differences which back our argument: " $\Omega \pi \dot{\alpha} \tau \rho \alpha \zeta \theta \eta \beta \eta \zeta$ है voเkol,

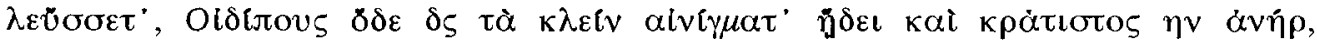

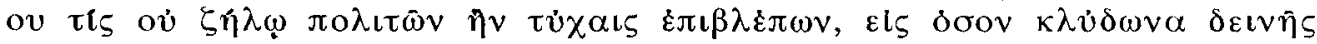

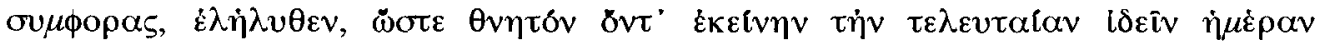

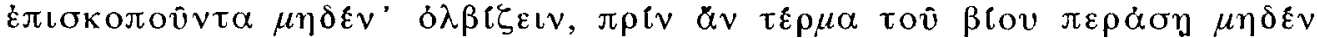

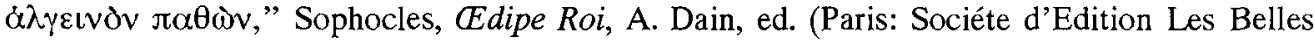
Lettres, 1972), II, 127-28; cf. T. R. Henn, The Lonely Tower. London: Methuen, 1950; reimpr. 1965), p. 284.

12. Variorum, p. 754. "The undiscovered country, from whose bourn/No traveller returns," W. Shakespeare. Hamlet (Harmondsworth: Penguin, 1980; reimpr. 1987), III.1.79-80, p. 124.

13. Variorum, p. 1047.

14. Variorum, p. 399; cf. W. B. Yeats, "Among School Children," en Collected Poems (London: Macmillan, 1980; reimpr. 1985), p. 244. 
15. Variorum, p. 1038.

16. For the symbolic complementation of characters in On Baile's Strand, see F. J. Torres Ribelles, Eternal Shadows: Symbolism in the Theatre of W. B. Yeats (Alicante: Publicaciones de la Universidad de Alicante, 1992), pp. 65-67.

17. Ellmann, op. cit., pp. 23, 284-85.

18. The Resurrection, a play of 1931 , was the last text where the three classic Yeatsian musicians were present. In A Full Moon in March and The King of The Great Clock Tower, both of 1935, they were substituted by the two 'attendants,' whereas in The Words upon the Window-Pane of 1934, The Herne's Egg of 1938, and Purgatory of 1939, they do not even appear. They will not come to light again, except in an allusion to them in the prologue of The Death of Cuchulain, until this play's last scene.

19. Variorum, p. 1051.

20. The indifference of the universe to man's death is a recurrent feature in Yeats's mature theatre. Apart from materializing in the lack of concern of the Blind Man who kills Cuchulain, it appears on other occasions, as in the insensitiveness of the complementary characters in the finale of On Baile's Strand, in the heedlessness of the soldiers in Calvary, or in the economical interest of the Fool in The Herne's Egg. Variorum, pp. 525, 786-87, 1034-38, and 1060.

21. Variorum, p. 1062; cf. ibid., p. 1051.

22. Variorum, p. 1063.

23. Cf. M. Good, W. B. Yeats and the Creation of a Tragic Universe (London: Macmillan, 1987), p. 151.

24. Collected Poems, p. 218, my italics.

25. Ibid, p. 218; cf. Variorum, p. 292-93.

26. Ibid., p. 453.

27. W. B. Yeats, Autobiographies (London: Macmillan, 1955; reimpr. 1987), p. 492.

28. Variorum, p. 511.

29. Ellmann, op. cit., pp. 244-45.

30. Autobiographies, pp. 462, 473-74.

31. "The Holy Mountain," Essays and Introductions, p. 472; cf. Autobiographies, p. 273.

32. N. Jeffares, "Yeats," in S. Lucy, ed., Irish Poets in English: The Thomas Davies Lectures in Anglo-Irish Poetry (Dublin: The Mercier Press, 1973), p. 116.

33. "J. M. Synge and the Ireland of his Time," Essays and Introductions, p. 322. 